Reviu Akuntansi dan Bisnis Indonesia, Vol. 3 No. 1, Hlm: 27-37, Juli 2019

Website: http://journal.umy.ac.id/index.php/rab

\title{
Pengaruh Jaminan Utang, Penurunan Arus Kas dari Aktivitas Operasi dan Fixed Asset Intensity Terhadap Revaluasi Aset Tetap
}

\author{
Drida Fioni*; Yeasy Darmayanti; Dandes Rifa \\ Program Studi Akuntansi Universitas Bung Hatta Padang
}

IN F O A R T I K E L

\section{Kata Kunci:}

Jaminan utang, Arus Kas

Operasi, Fixed Asset

Intensity; Revaluasi Aset

Tetap.

Jenis Artikel:

Penelitian Empiris

${ }^{*}$ Correspondence:

dridafioni23@gmail.com

\author{
A B S T R A K
}

\begin{abstract}
Aset tetap merupakan komponen penting dalam menjalankan operasional perusahaan dan untuk memastikan bahwa jumlah tercatat tidak berbeda secara material dari jumlah realnya, maka dibutuhkan revaluasi (penilaian kembali) yang harus dilakukan dengan keteraturan yang cukup ketat dengan menggunakan nilai wajar pada tanggal neraca. Frekuensi revaluasi aset tetap tidak diatur oleh standar akan tetapi bergantung pada pergerakan nilai wajar dari aset tetap. Penelitian ini bertujuan untuk mengumpulkan bukti-bukti empiris pengaruh jaminan utang, penurunan arus kas dari aktivitas operasi, dan fixed asset intensity terhadap keputusan perusahaan melakukan revaluasi aset tetap. Data dalam penelitian ini diperoleh dari laporan keuangan perusahaan yang dipublikasikan di Bursa Efek Indonesia (BEI) pada tahun 2011-2015. Sampel dalam penelitian ini dikumpulkan dengan menggunakan metode purposive sampling dimana sampel dipilih secara selektif. Sampel dalam penelitian ini sebanyak 71 perusahaan. Penelitian ini menggunakan regresi logistik. Hasilnya menunjukkan bahwa fixed asset intensity berpengaruh terhadap keputusan perusahaan melakukan revaluasi aset tetap. Namun variabel jaminan utang dan penurunan arus kas dari aktivitas operasi tidak berpengaruh terhadap keputusan perusahaan melakukan revaluasi aset tetap. Penelitian ini memperlihatkan nilai R Square sebesar 3,5\% yang artinya ada sekitar 96,5\% lagi variabel dependen dipengaruhi oleh faktor lain yang belum diteliti dalam penelitian ini.
\end{abstract}

(C) 2019 RAB. Published by Universitas Muhammadiyah Yogyakarta

\section{PENDAHULUAN}

Dewan Standar Akuntansi Keuangan (DSAK) Ikatan Akuntan Indonesia telah menetapkan tahun 2008 sebagai target dimana perbedaan-perbedaan mendasar antara PSAK dan IFRS sudah tidak ada lagi (Bintoro, 2010). Standar Akuntansi Keuangan Indonesia dalam beberapa tahun belakangan mengalami perubahan yang cukup signifikan dengan diberlakukannya standar yang berbasis internasional (IFRS). Konvergensi IFRS di Indonesia sudah dimulai pada tahun 2008 yang ditandai dengan terdapatnya perubahan-perubahan dalam PSAK sebagai akibat diadopsinya IFRS (Yulistia, dkk 2015).

Salah satu yang mengalami perubahan adalah revaluasi aset tetap, yang pada PSAK sebelumnya tidak diperkenankan dilakukan (PSAK 16 revisi 1994); harus memilih antara model biaya atau mobel revaluasi sebagai kebijakan akuntansi pengukuran atas aset tetap perusahaan (PSAK 16 revisi 2007). Aset tetap menjadi komponen penting dalam menjalankan operasional perusahaan. Oleh karenanya revaluasi (penilaian kembali) harus dilakukan dengan keteraturan yang 
cukup ketat untuk memastikan bahwa jumlah tercatat tidak berbeda secara material dari jumlah yang ditentukan dengan menggunakan nilai wajar pada tanggal neraca (Martani dkk, 2012).

Pelaksanaan revaluasi aset tetap tidak ditetapkan frekuensinya oleh standar keuangan, akan tetapi bergantung pada pergerakan nilai wajar dari aset tetap tersebut. Serta keputusan untuk memilih melakukan revaluasi atau tidakpun tergantung pada kebijakan manajer (Seng dan Su, 2010). Jadi pilihannya kembali kepada masing-masing manajer perusahaan tersebut, ingin memilih historical cost atau model revaluasi untuk pengukuran setelah pengakuan aset.

Terdapat beberapa faktor yang diduga mempengaruhi perusahaan melakukan revaluasi aset tetap. Faktor pertama adalah jaminan utang, Cotter dan Zimmer (1995) berpendapat bahwa ketika aset ditawarkan sebagai jaminan atas hutang, pemberi pinjaman mengharapkan nilai wajar saat ini dari aset yang ditawarkan sebagai jaminan atas hutang tersebut telah dicatat dalam laporan keuangan audit perusahaan. Dan dalam penelitiannya, Cotter dan Zimmer (1995) menemukan bahwa jaminan utang berpengaruh positif terhadap perusahaan untuk melakukan revaluasi aset tetap sedangkan penelitian yang dilakukan oleh Firmansyah dan Sherlita (2012) tidak berhasil menemukan pengaruh tingkat hutang jaminan terhadap keputusan perusahaan untuk melakukan revaluasi aset tetap.

Faktor selanjutnya yang berpengaruh terhadap keputusan perusahaan melakukan revaluasi adalah penurunan arus kas dari aktivitas operasi. Arus kas dari aktivitas operasi perusahaan yang mengalami penurunan dari tahun sebelumnya akan menyebabkan kekhawatiran yang besar oleh para kreditur dikarenakan semakin kecil arus kas dari aktivitas operasi semakin kecil pula kemungkinan pengembalian utang yang diberikan kreditur. Untuk meningkatkan kepercayaan kreditur perusahaan melakukan revaluasi aset agar aset yang dimiliki perusahaan diharapkan dapat meningkat. Dengan meningkatnya aset perusahaan maka kepercayaan kreditur akan meningkat kembali karena adanya peningkatan aset perusahaan (Firmansyah dan Sherlita, 2012).

Selanjutnya faktor yang berpengaruh terhadap keputusan perusahaan melakukan revaluasi aset tetap adalah fixed asset intensity. Menurut Nurjanah (2013) proporsi aset tetap yang besar akan mempengaruhi keputusan perusahaan melakukan revaluasi aset tetap. Hal ini dikarenakan aset tetap digunakan dalam sebagian besar kegiatan operasional perusahaan. Dengan meningkatnya proporsi aset tetap diharapkan akan meningkatkan laba perusahaan dimasa datang. Manihuruk dan Farahmita (2015) berhasil menemukan pengaruh fixed asset intensity terhadap keputusan perusahaan melakukan revaluasi aset tetap.

Penelitian ini dimotivasi oleh penelitian-penelitian sebelumnya yang masih belum konsisten dalam hasil. Penelitian yang dilakukan di luar Indonesia membuktikan bahwa manajer perusahaan memilih melakukan revaluasi aset tetap dipengaruhi oleh tingkat hutang jaminan (Cotter dan Zimmer, 1995), declining cash flows from operations (Cotter dan Zimmer, 1995), tetapi fixed asset intensity tidak mempengaruhi perusahaan dalam melakukan revaluasi aset tetap (Seng dan Su, 2010). Di Indonesia sendiri belum berhasil membuktikan bahwa jaminan utang, penurunan arus kas dari aktivitas operasi berpengaruh terhadap revaluasi aset tetap (Firmansyah dan Sherlita, 2012; Nurjanah, 2013; Yulistia dkk, 2015; Khairati, 2015; Saputra, 2016).

Karena masih terdapatnya ketidakkonsistenan hasil penelitian, maka peneliti tertarik untuk meneliti kembali pengaruh jaminan utang, penurunan arus kas dari aktifitas operasi, serta fixed asset intensity terhadap keputusan perusahaan melakukan revaluasi aset tetap di perusahaan manufaktur yang terdaftar di BEI tahun 2011-2015.

\section{TINJAUAN LITERATUR DAN PERUMUSAN HIPOTESIS}

\section{Teori Akuntansi Positif}

Teori akuntansi positif (TAP) adalah teori yang dikemukakan oleh Watts dan Zimmerman (1990), yang menjelaskan mengapa kebijakan akuntansi menjadi suatu masalah bagi perusahaan dan pihak-pihak yang berkepentingan dengan laporan keuangan, dan untuk memprediksi kebijakan akuntansi yang hendak dipilih oleh perusahaan dalam kondisi tertentu. Teori ini didasarkan pada 
pandangan bahwa perusahaan merupakan suatu "nexus of contracts", artinya perusahaan merupakan suatu muara bagi berbagai kontrak yang datang padanya.

Dorongan terbesar TAP adalah menjelaskan dan meramalkan pilihan standar manajemen melalui analisis atas biaya dan manfaat dari pengungkapan keuangan tertentu dalam hubungannya dengan berbagai individu dan pengalokasian sumberdaya ekonomi. Teori positif didasarkan pada adanya dalil bahwa manajer, pemegang saham, dan aparat pengatur atau politisi adalah rasional dan bahwa mereka berusaha untuk memaksimalkan kegunaan mereka, yang secara langsung berhubungan dengan kompensasi mereka (Belkaoui, 2007).

\section{Revaluasi Aset Tetap}

Revaluasi aset tetap adalah penilaian kembali aset tetap. Revaluasi sering dimaknai penilaian ulang yang menyebabkan nilai aset menjadi lebih tinggi, padahal revaluasi dapat menghasilkan nilai yang lebih rendah maupun lebih tinggi dari aset tercatat (Martani, 2012).

PSAK 16 (Revisi 2015) menyebutkan bahwa aset tetap yang nilai wajarnya diukur secara andal dicatat pada jumlah revaluasian, yaitu nilai wajar pada tanggal revaluasi dikurangi akumulasi penyusutan dan akumulasi rugi penurunan nilai setelah tanggal revaluasi. Revaluasi dilakukan dengan keteraturan yang cukup reguler untuk memastikan bahwa jumlah tercatat tidak berbeda secara material dengan jumlah yang ditentukan dengan menggunakan nilai wajar pada akhir periode pelaporan.

Jika jumlah tercatat aset meningkat akibat revaluasi, maka kenaikan tersebut diakui dalam penghasilan komprehensif lain dan terakumulasi dalam ekuitas pada bagian surplus revaluasi. Akan tetapi, kenaikan tersebut diakui dalam laba rugi hingga sebesar jumlah penurunan nilai aset yang sama akibat revaluasi yang pernah diakui sebelumnya dalam laba rugi. Jika jumlah tercatat aset turun akibat revaluasi, maka penurunan tersebut diakui dalam laba rugi. Akan tetapi, penurunan nilai tersebut diakui dalam penghasilan komprehensif lain sepanjang tidak melebihi saldo surplus revaluasi untuk aset tersebut. Penurunan nilai yang diakui dalam penghasilan komprehensif lain tersebut mengurangi jumlah akumulasi dalam ekuitas pada bagian surplus revaluasi (PSAK 16, revisi 2015).

\section{Jaminan Utang}

Jaminan utang adalah suatu hak yang diperoleh kreditur (berpiutang) untuk menimbulkan keyakinan bahwa debitur (berutang) akan memenuhi kewajibannya kepada kreditur. Menurut Firmansyah dan Sherlita (2012), perusahaan akan lebih mudah memperoleh dana pinjaman ketika pinjaman tersebut dijaminkan oleh aset perusahaan dan biaya pinjaman pun akan lebih kecil dikeluarkan dibandingkan dengan pinjaman tanpa jaminan.

Hal ini dikarenakan pinjaman tanpa jaminan lebih beresiko bagi kreditur terutama ketika perusahaan dilikuidasi dan ketika kreditur merasa perusahaan sulit untuk melunasi pinjaman tersebut. Dalam menjaminkan aset untuk pinjaman, kreditur mengharapkan bahwa aset yang dijaminkan tersebut telah dicatat sesuai dengan nilai wajar yang berlaku saat ini. Hal ini disebabkan karena dengan pencatatan nilai aset tersebut, kreditur dapat memperkirakan dengan lebih mudah menetapkan batas maksimum pinjaman yang dapat diberikan kepada perusahaan dengan aset yang dijaminkan tersebut.

\section{Penurunan Arus Kas Dari Aktivitas Operasi}

Pada PSAK 2 (Revisi 2015) menyebutkan bahwa informasi tentang arus kas entitas berguna dalam menyediakan pengguna laporan keuangan dasar untuk menilai kemampuan entitas dalam menghasilkan kas dan setara kas serta menilai kebutuhan entitas untuk menggunakan arus kas tersebut. Pengguna laporan keuangan entitas berkepentingan untuk mengetahui bagaimana entitas menghasilkan dan menggunakan kas dan setara kas. Pada dasarnya, entitas membutuhkan kas dengan alasan yang sama meskipun terdapat perbedaan dalam aktivitas penghasil pendapatan utama 
(revenue-producing activities). Entitas membutuhkan kas untuk melaksanakan usahanya, melunasi kewajibannya, dan membagikan dividen kepada investor.

Jika terjadi penurunan arus kas dari aktivitas operasi perusahaan dari tahun sebelumnya tentunya akan menyebabkan kekhawatiran yang besar bagi para kreditur dikarenakan semakin kecil arus kas dari aktivitas operasi semakin kecil pula kemungkinan pengembalian utang yang diberikan kreditur. Untuk meningkatkan kepercayaan kreditur perusahaan melakukan revaluasi aset agar aset yang dimiliki perusahaan diharapkan dapat meningkat. Dengan meningkatnya aset perusahaan maka kepercayaan kreditur akan meningkat kembali karena adanya peningkatan aset perusahaan (Firmansyah dan Egy, 2012)

Fixed Asset Intensity

Menurut Tay (2009), fixed asset intensity (intensitas aset tetap) merupakan jumlah proporsi dari aset tetap yang dimiliki perusahaan. Aset tetap merupakan investasi perusahaan yang menyerap sebagian besar modal perusahaan, sebab dari segi jumlah dana, aset tetap memerlukan dana yang relatif besar (Ernawati, 2014).

Proporsi aset tetap yang besar akan mempengaruhi keputusan perusahaan melakukan revaluasi aset tetap. Hal ini dikarenakan aset tetap digunakan dalam sebagian besar kegiatan operasional perusahaan. Dengan meningkatnya proporsi aset tetap diharapkan akan meningkatkan laba perusahaan dimasa datang (Nurjanah, 2013).

\section{Penurunan Hipotesis}

Pengaruh Jaminan utang terhadap Revaluasi Aset Tetap

Penelitian yang dilakukan oleh Cotter dan Zimmer (1995) berpendapat bahwa ketika aset ditawarkan sebagai jaminan atas utang, pemberi pinjaman mengharapkan nilai wajar saat ini dari aset yang ditawarkan sebagai jaminan atas hutang tersebut telah dicatat dalam laporan keuangan audit perusahaan. Karena revaluasi aset dapat meningkatkan kredibilitas laporan yang dipublikasikan perusahaan. Jika ini adalah tujuan dari revaluasi, ada kemungkinan revaluasi tersebut dilakukan pada saat kenaikan tingkat hutang yang dijamin. Ini akan menjadi solusi kontrak yang efisien ketika biaya penilaian wajar aset yang dijaminkan lebih kecil dari kenaikan biaya utang yang akan terjadi jika utang diperoleh tanpa jaminan.

Sebaliknya, penelitian yang dilakukan oleh Firmansyah dan Sherlita (2012), Cotter (1999) menemukan bahwa jaminan utang tidak mempengaruhi keputusan perusahaan untuk melakukan revaluasi aset tetap. Hal tersebut dikarenakan perusahaan dapat menjaminkan aset lain selain aset tetap yang dimiliki oleh perusahaan untuk memperoleh dana utang jaminan.

Berdasarkan dari hasil penelitian diatas, maka hipotesis yang diajukan adalah:

\section{$\boldsymbol{H}_{\boldsymbol{I}}$ : Jaminan utang berpengaruh terhadap keputusan perusahaan dan melakukan revaluasi aset tetap.}

Pengaruh Penurunan Arus Kas dari Aktivitas Operasi terhadap Revaluasi Aset Tetap

Menurut Seng dan Su (2010) penurunan arus kas dari aktivitas operasi dapat menyebabkan pemberi pinjaman khawatir dengan likuiditas perusahaan. Cotter dan Zimmer (1995) dalam Seng dan Su (2010) berpendapat bahwa upward revaluation merupakan sinyal nilai yang lebih tinggi pada aset perusahaan sehingga dapat meyakinkan pemberi pinjaman atas kemampuan perusahaan untuk membayar utang. Oleh karena itu, perusahaan dengan penurunan arus kas operasi akan merevaluasi aset tetap.

Akan tetapi beberapa perusahaan di Indonesia menemukan hasil sebaliknya, yaitu penurunan arus kas dari aktivitas operasi tidak berpengaruh terhadap keputusan perusahaan untuk 
melakukan revaluasi aset tetap (Firmansyah dan Sherlita, 2010; Nurjanah, 2013; Yulistia, dkk, 2015; Saputra, 2016).

Berdasarkan dari hasil penelitian diatas, maka hipotesis yang diajukan adalah:

H: Penurunan arus kas dari aktivitas operasi berpengaruh terhadap keputusan perusahaan melakukan revaluasi aset tetap.

Pengaruh Fixed Asset Intensity terhadap Revaluasi Aset Tetap

Tay (2009) menemukan bahwa fixed asset intensity memiliki pengaruh terhadap keputusan perusahaan untuk melakukan revaluasi aset tetapnya, dimana dia memiliki argumen bahwa revaluasi layak diperhatikan dimana aset tetap merupakan porsi terbesar dari total aset, yang akan meningkatkan nilai perusahaan dan karenanya memiliki potensi yang besar dalam meningkatkan basis aset. Selain itu revaluasi juga dilakukan untuk mengurangi pelaporan profitabilitas perusahaan, baik melalui depresiasi yang lebih besar, maupun dengan peningkatan basis aset yang digunakan untuk mengukur return on equity. Manihuruk dan Farahmita (2015) juga menemukan bahwa fixed asset intensity berpengaruh signifikan positif terhadap pilihan metode revaluasi aset tetap.

Sebaliknya beberapa peneliti menemukan bahwa fixed asset intensity tidak berpengaruh terhadap keputusan perusahaan melakukan revaluasi aset tetap (Seng dan Su, 2010; Yulistia dkk, 2012; Khairati, 2015). Berdasarkan dari hasil penelitian diatas, maka hipotesis yang diajukan adalah:

\section{$\boldsymbol{H}_{3} \quad$ : Fixed Asset Intensity Berpengaruh Terhadap Keputusan Perusahaan Melakukan Revaluasi Aset Tetap.}

\section{Kerangka Konseptual}

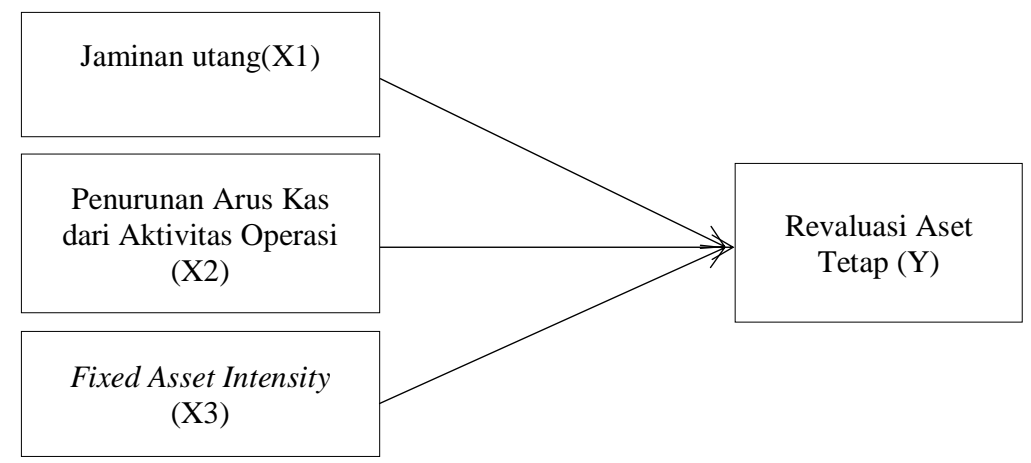

Gambar 2.1 Kerangka Konseptual

\section{METODE PENELITIAN}

\section{Sumber Data, Populasi dan Sampel}

Data dalam penelitian ini bersumber dari situs resmi Bursa Efek Indonesia yaitu www.idx.co.id. Penelitian ini menggunakan data sekunder, berupa data laporan keuangan tahunan perusahaan. Populasi penelitian ini adalah perusahaan manufaktur yang terdaftar di BEI (Bursa Efek Indonesia) pada tahun 2011-2015. Untuk mewakili populasi, sampel dipilih dengan menggunakan metode purposive sampling (kriteria yang dikehendaki). Kriteria sampel dalam penelitian ini adalah sebagai berikut: 
1. Perusahaan manufaktur yang terdaftar di Bursa Efek Indonesia pada tahun 2011-2015.

2. Perusahaan menerbitkan laporan keuangan yang lengkap dan dipublikasikan berturut-turut selama periode pengamatan.

3. Perusahaan yang menggunakan mata uang rupiah dalam laporan keuangannya.

4. Perusahaan manufaktur yang memiliki jaminan utang

Definisi Operasional Variabel dan Pengukurannya

Jaminan utang

Jaminan utang adalah suatu hak yang diperoleh kreditur (berpiutang) untuk menimbulkan keyakinan bahwa debitur (berutang) akan memenuhi kewajibannya kepada kreditur (Firmansyah dan Sherlita, 2012). Jaminan utang dapat diukur dengan menggunakan skala nominal yang bersifat variabel dummy, diberi angka 1 jika jaminan utang perusahaan mengalami peningkatan pada tahun revaluasi, dan diberi angka 0 jika jaminan utang perusahaan tidak mengalami peningkatan pada tahun revaluasi (Firmansyah dan Sherlita, 2012).

\section{Penurunan Arus Kas Dari Aktivitas Operasi}

Penurunan arus kas dari aktivitas operasi atau declining cash flows from operation (CFFO) merupakan penurunan sejumlah kas dan setara kas dari kegiatan rutin perusahaan (Seng dan Su, 2010). Penurunan arus kas dari aktivitas operasi dapat diukur melalui perubahan arus kas dari aktivitas operasi selama dua tahun dibagi dengan jumlah asset berwujud (Firmansyah dan Sherlita, 2012).

$$
\text { CFFO }=\frac{\text { Perubahan dalam CFFO dalam } 2 \text { tahun }}{\text { Total Aset Tetap }}
$$

Fixed Asset Intensity

Fixed asset intensity (intensitas aset tetap) merupakan proporsi aset perusahaan yang terdiri dari aktiva tetap (Tay, 2009). Fixed Aset Intensity diukur dengan menggunakan rasio seperti yang digunakan dalam penelitian (Seng dan Su, 2010).

$$
\text { Fixed asset intensity }=\frac{\text { Book value of total fixed asset }}{\text { total assets }}
$$

\section{Revaluasi Aset Tetap}

Revaluasi aset tetap adalah penilaian kembali aset tetap. Revaluasi sering dimaknai penilaian ulang yang menyebabkan nilai aset menjadi lebih tinggi, padahal revaluasi dapat menghasilkan nilai yang lebih rendah maupun lebih tinggi dari aset tercatat (Martani, 2012). Revaluasi aset disini di ukur dengan metode dummy. Revaluasi aset dikategorikan berdasarkan perusahaan yang melakukan dan tidak melakukan revaluasi aset. Untuk perusahaan yang melakukan revaluasi aset diberi nilai 1, dan perusahaan yang tidak melakukan revaluasi aset diberi nilai 0. (Seng dan Su, 2010).

\section{Metode Analisa Data}

Untuk menguji hipotesis dalam penelitian ini menggunakan metode regresi logistik (logistic regression). Metode ini dipilih karena variabel dependen dalam penelitian ini adalah keputusan perusahaan untuk melakukan revaluasi aset tetap yang merupakan variabel dummy/kategori, 
sedangkan variabel independen menggunakan data metrik. Model regresi logistik yang digunakan untuk menguji hipotesis adalah:

$$
\operatorname{Ln} \frac{R M}{1-R M}=\alpha_{0}+\beta_{1} \text { THJit }+\beta_{2} \text { CFFOit }+\beta_{3} \text { INTENSITYit }+\varepsilon
$$

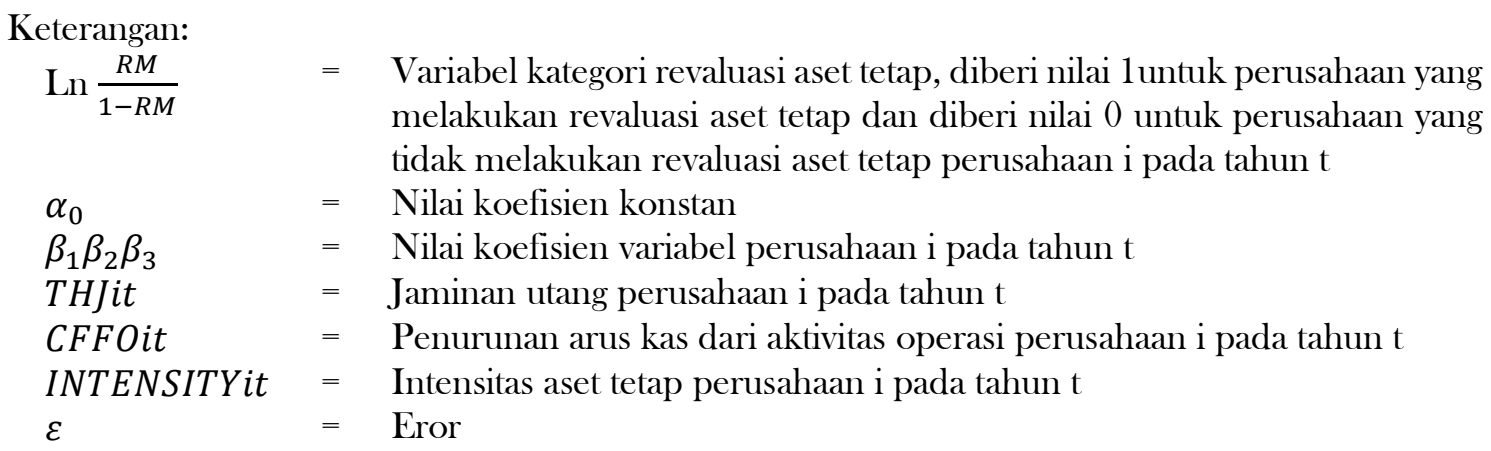

\section{HASIL DAN PEMBAHASAN}

Prosedur Pengambilan Sampel

Tujuan dari penelitian ini adalah untuk mendapatkan bukti secara empiris tentang faktorfaktor yang mempengaruhi perusahaan dalam melakukan revaluasi aset tetap pada perusahaan manufaktur yang terdaftar di Bursa Efek Indonesia dari tahun 2011-2015. Sampel yang dipilih pada penelitian ini menggunakan metode purposive sampling berdasarkan kriteria tertentu yang telah dijelaskan pada bab sebelumnya. Data didapat dari laporan keuangan perusahaan yang telah diterbitkan di website IDX (Indonesian Stock Exchange). Adapun proses pengambilan sampel dalam penelitian ini dapat dilihat pada tabel 4.1 berikut:

Tabel 1 Proses Pengumpulan Sampel

\begin{tabular}{lcc}
\hline Perusahaan manufaktur yang terdaftar di BEI dari tahun 2011-2015 & 146 & $100 \%$ \\
Perusahaan yang tidak menerbitkan laporan keuangan secara lengkap & $(23)$ & $16 \%$ \\
Perusahaan yang tidak menggunakan mata uang rupiah & $(33)$ & $23 \%$ \\
Perusahaan yang tidak memiliki jaminan utang & $(19)$ & $13 \%$ \\
Perusahaan yang dijadikan sampel & 71 & $48 \%$ \\
\hline
\end{tabular}

Dari tabel 1 di atas dapat dilihat bahwa jumlah perusahaan yang dijadikan sampel dalam penelitian ini sebanyak 71 perusahaan manufaktur yang terdaftar di BEI pada tahun 2011-2015. Jadi jumlah observasi dalam penelitian ini adalah 355 . Berikut adalah klasifikasi perusahaan yang melakukan revaluasi aset tetap dan yang tidak melakukan revaluasi aset tetap selama tahun pengamatan dapat dilihat pada tabel 2 .

Tabel 2 Kebijakan Revaluasi Aset Perusahaan Sampel

\begin{tabular}{cccc}
\hline Tahun & Total Sampel & Melakukan revaluasi & Tidak melakukan revaluasi \\
\hline 2011 & 71 & 4 & 67 \\
2012 & 71 & 4 & 67 \\
2013 & 71 & 6 & 65 \\
2014 & 71 & 6 & 65 \\
2015 & 71 & 13 & 58 \\
Total & 355 & 33 & 322 \\
\hline
\end{tabular}

Sumber: Olahan, 2017 


\section{Statistik Deskriptif}

Setelah seluruh data dan informasi dikumpulkan maka proses pengolahan data dapat segera dilakukan. Proses pengolahan data dapat dilakukan dengan menggunakan program SPSS 16.0. Pengolahan pertama yang dilakukan adalah melihat statistik deskriptif dari data. Berdasarkan dari pengolahan data yang dilakukan diperoleh ringkasan hasil sebagai berikut:

Tabel 3 Descriptive Statistics

\begin{tabular}{lrrrrr} 
& N & Minimum & Maksimum & Mean & $\begin{array}{c}\text { Std. } \\
\text { Deviation }\end{array}$ \\
\hline Revaluasi aset & 355 & 0.00 & 1.00 & .0930 & .29078 \\
Hutang jaminan & 355 & 0.00 & 1.00 & .6930 & .46192 \\
Penurunan arus kas aktifitas operasi & 355 & -2 & 22 & .11 & 1.253 \\
Fixed asset intensity & 355 & 0 & 1 & .38 & .213 \\
Valid N (listwise) & 355 & & & & \\
\hline
\end{tabular}

Sumber: Hasil Pengolahan Data, 2017

Kelayakan Model Regresi

Hasil output SPSS menunjukkan bahwa nilai Hosmer and Lemeshow sebesar 6,615 dan nilai signifikan pada 0,579 oleh karena nilai ini diatas 0,050 maka model dikatakan fit dan model dapat diterima karena cocok dengan data observasi.

Tabel 4 Hasil Uji Hosmer and Lemeshow Test

\begin{tabular}{cccc}
\hline Step & Chi-square & df & Sig. \\
\hline 1 & 6.615 & 8 & .579
\end{tabular}

Sumber: Hasil Pengolahan Data, 2017

Uji Model Fit

Menilai model fit dapat dilihat dari nilai statistik -2LogL. Dilihat dari hasil output SPSS nilai -2LogL pada Blok 0 sebesar 219,623 dan nilai -2 LogL pada blok 1 sebesar 213,894. Berarti ada penurunan nilai sebesar 5,729, karena adanya penurunan nilai tersebut maka model dapat diterima karena cocok dengan data (model fit dengan data) dan hal ini juga mengindikasikan bahwa model regresi tersebut adalah regresi yang baik.

Tabel 5 Hasil Uji Model Fit

\begin{tabular}{cc}
\hline$-2 \log$ likelihood & Constant \\
\hline 0 & 219,623 \\
1 & 213,894 \\
\hline
\end{tabular}

Sumber: Hasil pengolahan data, 2017

Uji Nagelkerke’s R Square

Nilai output SPSS nilai Cox and Snell's R^2 sebesar 0,016 dan nilai Nagelkerke's R Square 0,035 yang berarti bahwa variabel independen yang digunakan dalam penelitian ini mampu menjelaskan mengenai nilai wajar sebesar 3,5\% dan sementara 96,5\% sisanya dijelaskan oleh faktor lain yang tidak digunakan dalam penelitian ini.

Tabel 6 Hasil Uji Nagelkerke's R Square

\begin{tabular}{cccc}
\hline Step & -2 Log likelihood & Cox \& Snell R Square & Nagelkerke R Square \\
\hline 1 & $213.894^{\mathrm{a}}$ & .016 & .035 \\
\hline
\end{tabular}

Sumber: Hasil pengolahan data, 2017 


\section{Uji Hipotesis}

Pengujian hipotesis ini dilakukan untuk mengetahui apakah faktor-faktor yang mempengaruhi pemilihan metode revaluasi aset tetap pada perusahaan manufaktur yang terdaftar di BEI pada tahun 2011-2015. Uji hipotesis menggunakan regresi logistik dengan tingkat signifikan 0,05 (5\%). Hasil pengujian regresi logistik dapat dilihat dari hasil output SPSS.

Tabel 7 Hasil Uji Hipotesis

\begin{tabular}{lcccc}
\hline Variabel Independen & B & Sig & $\boldsymbol{\alpha}$ & Kesimpulan \\
\hline Jaminan Utang & 0.546 & 0.222 & 0.05 & Ditolak \\
Penurunan CFO & -0.082 & 0.804 & 0.05 & Ditolak \\
Fixed Aset Intensity & 1.674 & 0.047 & 0.05 & Diterima \\
Constant & -3.368 & & & \\
\hline
\end{tabular}

Variabel Dependen: Revaluasi Aset Tetap

Sumber: Hasil pengolahan data, 2017

Jaminan utang dan Revaluasi Aset Tetap

Pengujian hipotesis 1 digunakan untuk membuktikan pengaruh jaminan utang terhadap keputusan perusahaan melakukan revaluasi aset tetap. Hasil pengolahan data menunjukkan bahwa nilai signifikan variabel jaminan utang adalah 0,222 . Hal tersebut membuktikan bahwa nilai signifikan jaminan utang di atas cut off hipotesis yaitu 0,05 . Hasil pengujian hipotesa dengan analisa regresi logistik menunjukkan bahwa variabel jaminan utang tidak berpengaruh terhadap keputusan perusahaan dalam melakukan revaluasi aset tetap.

Revaluasi aset tetap tidak tergantung pada peningkatan atau penurunan jaminan utang perusahaan. Hal tersebut diduga bahwa perusahaan dapat menjaminkan aset lain selain aset tetap yang dimiliki oleh perusahaan untuk memperoleh dana jaminan utang. Hal ini disebabkan karena kreditur lebih tertarik dengan jaminan aset yang lebih likuid dibandingkan dengan jaminan berupa aset tetap.

Hasil penelitian ini sejalan dengan penelitian yang dilakukan oleh Firmansyah dan Sherlita (2012), Cotter (1999) yang menemukan bahwa jaminan utang tidak mempengaruhi keputusan perusahaan untuk melakukan revaluasi aset tetap. Revaluasi aset tetap tidak bergantung pada peningkatan atau penurunan jaminan utang perusahaan.

\section{Penurunan Arus Kas Dari Aktivitas Operasi dan Revaluasi Aset Tetap}

Pengujian hipotesis 2 digunakan untuk membuktikan pengaruh penurunan arus kas dari aktivitas operasi terhadap keputusan perusahaan melakukan revaluasi aset tetap. Hasil pengolahan data menunjukkan bahwa nilai signifikan variabel penurunan arus kas dari aktivitas operasi (CFFO) adalah 0,799. Hal tersebut membuktikan bahwa nilai signifikan penurunan arus kas dari aktivitas operasi di atas cut off hipotesis yaitu 0,05 . Hasil pengujian hipotesa dengan analisa regresi logistik menunjukkan bahwa variabel penurunan arus kas dari aktivitas operasi tidak berpengaruh terhadap keputusan perusahaan dalam melakukan revaluasi aset tetap.

Penurunan arus kas dari aktivitas operasi tidak menjadi masalah yang besar bagi kreditur ketika perusahaan tersebut masih memiliki tingkat leverage yang rendah. Hal tersebut dikarenakan jika perusahaan dilikuidasi, maka aset yang dimiliki diharapkan masih mampu untuk melunasi hutangnya. Tinggi rendahnya penurunan arus kas dari aktivitas operasi mungkin tidak mempengaruhi perusahaan untuk melakukan revaluasi aset tetap, hal ini dikarenakan arus kas dari aktivitas operasi hanya satu dari tiga bagian arus kas perusahaan secara keseluruhan.

Hasil penelitian ini sejalan dengan penelitian yang dilakukan oleh Firmansyah dan Sherlita (2010), Nurjalah (2013), Yulistia, dkk (2015), Saputra (2016) yang menemukan bahwa penurunan arus kas dari aktivitas operasi tidak berpengaruh terhadap keputusan perusahaan melakukan revaluasi aset tetap. 
Fixed Asset Intensity dan Revaluasi Aset Tetap

Pengujian hipotesis 3 digunakan untuk membuktikan pengaruh fixed asset intensity terhadap keputusan perusahaan melakukan revaluasi aset tetap. Hasil pengolahan data menunjukkan bahwa nilai signifikan variabel fixed asset intensity adalah 0,047 . Hal tersebut membuktikan bahwa nilai signifikan fixed asset intensity dibawah cut off hipotesis yaitu 0,05 . Hasil pengujian hipotesa dengan analisa regresi logistik menunjukkan bahwa variabel fixed asset intensity berpengaruh terhadap keputusan perusahaan dalam melakukan revaluasi aset tetap.

Hasil penelitian ini menunjukkan bahwa variabel fixed asset intensity merupakan salah satu faktor yang berpengaruh dalam melakukan revaluasi aset tetap. Perusahaan dengan intensitas aset tetap yang besar akan semakin besar kemungkinan memilih menggunakan metode revaluasi pada pencatatan aset tetap. Intensitas aset tetap dapat menggambarkan ekspektasi kas yang dapat diterima jika aset tetap dijual, maka perusahaan dengan intensitas aset tetap yang tinggi cenderung akan lebih memprioritaskan metode pencatatan dan pengakuan aset tetap yang lebih mencerminkan nilai aset yang sesungguhnya.

Hasil penelitian ini sejalan dengan penelitian yang dilakukan oleh Tay (2009), Manihuruk dan Farahmita (2015) yang menemukan fixed asset intensity memiliki pengaruh terhadap keputusan perusahaan untuk melakukan revaluasi aset tetapnya. Tay (2009) memiliki argumen bahwa revaluasi layak diperhatikan dimana aset tetap merupakan porsi terbesar dari total aset, yang akan meningkatkan nilai perusahaan dan karenanya memiliki potensi yang besar dalam meningkatkan basis aset. Selain itu revaluasi juga dilakukan untuk mengurangi pelaporan profitabilitas perusahaan, baik melalui depresiasi yang lebih besar, maupun dengan peningkatan basis aset yang digunakan untuk mengukur return on equity.

\section{KESIMPULAN}

Penelitian ini bertujuan untuk mengetahui pengaruh jaminan utang, penurunan arus kas dari aktivitas operasi dan fixed asset intensity terhadap keputusan perusahaan melakukan revaluasi aset tetap pada perusahaan manufaktur yang terdaftar di BEI pada tahun 2011-2015. Jumlah perusahaan manufaktur yang dijadikan sampel dalam penelitian ini adalah sebanyak 71 perusahaan dengan tingkat signifikansi 0,05 (5\%), maka dapat ditarik kesimpulan bahwa variabel jaminan utang tidak berpengaruh terhadap keputusan perusahaan melakukan revaluasi aset tetap, variabel penurunan arus kas dari aktivitas operasi tidak berpengaruh terhadap keputusan perusahaan dalam melakukan revaluasi aset tetap, dan variabel fixed asset intensity berpengaruh terhadap keputusan perusahaan melakukan revaluasi aset tetap.

\section{DAFTAR PUSTAKA}

Belkaoui, A. R. (2007). Accounting Theory. Jakarta: Salemba Empat.

Bintoro, I. (2010). Konvergensi PSAK-IFRS Sebagai Langkah Pemantapan dalam Persiapan

Penerapan IFRS. Diakses dari: www.informasi-seminar.com.

Cotter \& Zimmer. (1995). Asset Revaluations and Assessment of Borrowing Capacity, ABACUS, 31.

Cotter, J. (1999). Asset Revaluations and Debt Contracting. ABACUS, 35.

Ernawati. (2014). Analisis Penerapan Standar Akuntansi Keuangan (PSAK NO 16) atas Aset Tetap pada PT. Pelayaran Liba Marindo Tanjungpinang, Skripsi, Universitas Maritim Raja Ali Haji.

Firmansyah, E. \& Sherlita, E. (2012). Pengaruh Negosiasi Debt Contracts Dan Political Cost Terhadap Perusahaan Untuk Melakukan Revaluasi Aset Tetap (Studi Empiris Pada Perusahaan Yang Terdaftar Di Bursa Efek Indonesia Tahun 2010). Seminar Nasional Akuntansi \& Bisnis (1). 
Ikatan Akuntan Indonesia. (2015). Standar Akuntansi Keuangan, Jakarta: Ikatan Akuntan Indonesia.

Khairati, A. (2015). Pengaruh Leverage, Firm Size and Fixed Asset Intensity terhadap Keputusan Perusahaan Melakukan Revaluasi Aset Tetap. Skripsi. Universitas Bung Hatta, Padang.

Manihuruk, T. N., \& Farahmita, A. (2015). Analisis Faktor-Faktor yang Mempengaruhi Pemilihan Metode Revaluasi Aset Tetap pada Perusahaan yang Terdaftar di Bursa Saham Beberapa Negara ASEAN, Seminar Nasional Akuntansi.

Martani, D., Siregar, S. V., Wardhani, R., Farahmita, A., \& Tanujaya, E. (2012). Akuntansi Keuangan Menengah Berbasis PSAK, Jakarta: Salemba Empat.

Nurjanah, A. (2013). Faktor-faktor yang Berpengaruh Terhadap Keputusan Revaluati Aset Tetap Pada Perusahaan yang Listing di Bursa Efek Indonesia Tahun 2011. Skripsi, Universitas Pendidikan Indonesia, Bandung.

Saputra, A. (2016). Pengaruh Negosiasi Dept Contract, Political Cost, Merger dan Akuisis Terhadap Keputusan Perusahaan Melakukan Revaluasi Aset Tetap. Skripsi, Universitas Bung Hatta, Padang.

Seng, D. \& Su, J. (2010). Managerial Incentives Behind Fixed Asset Revaluation. International Journal of Business Research, 10(2).

Tay, I. (2009). Fixed Asset Revaluation: Management Incentives and Market Reactions. Thesis, Lincoln University, New Zeland.

Watts, R. L. \& Zimmerman, J. L. (1990). Positive Accounting Theory: A Ten Year Perspective. The Accounting Review 65 (1), 131 - 156.

Yulistia, R. M., Fauziati, P., Minovia, A. F. \& Khairati, A. (2015). Pengaruh Leverage, Arus Kas Operasi, Ukuran Perusahaan dan Fixed Asset Intensity Terhadap Revaluasi Aset Tetap, Seminar Nasional Akuntansi. 